\title{
Underwriting in a Competitive Market
}

\author{
by John J. Roberts *
}

The property-casualty insurance business in the United States is still in one of the longest price wars in history.

Thus far it has concentrated in the commercial lines, but so many companies covet the apparent stability of personal lines that it is all too clear what is about to happen there.

Much of the price competition is what we might call shallow, that is, it is based on short-term market exigencies or non-insurance objectives, such as investment gain. Most of it is not based on long-term market strategy, nor is it grounded in lower loss or expense costs.

For many, therefore, the price competition is the vehicle by which they destroy themselves. The competition is both causing and reflecting profound changes in the industry. Some will come out better than before and some worse, perhaps some not at all. The gap between the best, most disciplined and most market-oriented companies and all the others, which has been quietly opening up for the twenty years, will open wider and more rapidly.

It is worth everyone's while, therefore, to try to understand what is going on.

A service business is best examined in termes of those it serves, so let us look at the three tiers of the insurance business, arranged by the size of the client's insurance needs.

At the top, the largest corporations are retaining more of their most predictable risks and the attendant premium dollars. In effect, the risk management movement is reducing the demand for fixed-cost insurance from that market segment.

At the bottom tier in size, typically personal lines, are to be found the most sophisticated, low-cost providers of fixed-cost insurance in our business, the directresponse and exclusive agency direct writers. Fighting them on price without matching them on operating cost and underwriting discipline is a good way to lose money, market share and self-esteem.

In the middle market is an overpopulation of standard companies selling standard coverages with only price to distinguish them in the eyes of the ultimate customer.

\footnotetext{
* Chairman, American International Underwriters Corporation, New York.
} 
The economics of the three tier market suggest that the price competition could go on quite a while longer and that the strategy of waiting for the turn in the cycle is no strategy at all.

My own company has tried to improve its position, first, by cooperating with our large corporate clients and their brokers in saving money and providing worldwide service, second, by keeping our overhead expenses down and, third, by offering differentiated products and serving difficult markets where one can attract business on a basis other than price.

All that has enabled us to stand by our traditional emphasis on underwriting at a profit. Underwriting profit is not only a key measure of professional success and of the value, to those who pay the premiums, but also of an insurer's services. It is also a valuable management resource because it enables professionals to judge themselves, which in turn enables those above them in management to give them more freedom. Insurance began as an adventure, and much is surely lost by those who have to turn it into a bureaucracy.

The change in attitude toward underwriting profit is thus one way in which today's price competition is widening the gap - strengthening the strong and weakening the weak.

Still we all feel the pressure on prices, and price competition deserves a yet closer look. Since much of today's competition began with an awakening to the time value of money, I shall continue to call it cash flow underwriting, even though in many companies the cash flow has turned out to be, not a river, but a tide which also ebbs.

What is wrong about cash flow underwriting ? After all, insurers, reinsurers, agents, brokers, regulators and corporate treasurers all have a pretty good grip on the financial aspects of insurance. Knowledge is fine, but there can be danger in how it is put to use.

Today it is being used to soften the standards of acceptable performance in the insurance business, while making that same business more difficult. The knowledge is employed to inspire and to forgive shortsighted competitive behavior. It is conceived as a sophistication but enjoyed as an indulgence.

Besides the desire to put money to work, driving the competition are market and cross-cultural considerations. Insurers remember how much they lost by pulling out of markets in the mid-1970's and are not about to do so again. Others believe they are investing by setting themselves up in new markets.

Insurers from different countries respond to different accounting conventions and tax laws. Some see insurance as a forward market in foreign exchange.

Different insurers look differently at their products and their markets, at growth and profit, at losses and expenses, at underwriting result and total return, at the income statement for today and the balance sheet for tomorrow. All of us want to think of everything, but in reality each of us puts some things ahead of others. Where competitors purse different objectives, their competition is apt to be a baffling, exasperating mess.

There are five reasons to expect this fever of cash flow underwriting to end badly.

First, it implicitly discards the most widely accepted measure of underwriting performance - the combined ratio. 
Obviously the ratio ignores some components of insurer profit. But it measures better than anything else the market worth of the insurer's services. Maybe that is why not everyone likes it anymore.

Most important, the ratio is the key to a whole system of interdependent beliefs which enables us somehow to manage the insurance business at all. The business is hard to manage in the absence of a cartel and has a certain tendency to spin out of control.

Second, cash flow underwriting shifts the locus of decision making in an insurance operation away from underwriting people and toward financial and administrative people.

The reason is that when underwriting margins are planned to be negative, they lose meaning to those who live by them. But revenues, investment income and operating economies gain in importance.

Financial people will translate their analysis into unmanageable directives. They will surely bring yet more emphasis on short-term and quantitative measures, at the sacrifice of strategy and strong market position.

Administrators will, just as surely, focus on small reductions in expense. Having squeezed dollar expenses as hard as they know how, they will look to the way expenses are reported.

Then they will press for growth in the denominator of the expense ratio.

There is no reason why a struggle for written premium to push the expense ratio down would be any less violent than a struggle for cash premium to push investment income up.

A concern about administrators and financiers pushing underwriters aside in insurance may sound stodgy too. But the same American business schools which preached transferable management and finance for decades now attribute many of the country's industrial problems to a lack of long corporate vision and to a decline in the status of creative and operating talent.

The third and fourth problems with cash flow underwriting have to do with the risk characteristics of an insurer's book of business.

Emphasis on total return pushes an insurer toward liability insurance and toward excess levels, because they offer the longest asset float.

Price competition, which began five years ago in commercial property insurance, is now most unruly in commercial excess casualty. Costs there are most difficult to know, mistakes are longest hidden and accepted standards of price adequacy are rare.

Fourth, the concern for float works not just on the seller of insurance but on the buyers as well. The insurance culture is a single one and ideas move freely within it.

When the buyer responds to the same financial analysis we have been attributing to sellers, he naturally wants to hold onto as much cash as possible for as long as possible.

That means retaining, in one way or another, the most predictable exposures and only buying fixed-cost insurance for what is left. 
Much insurance pricing is on the tacit assumption that whole exposures are insured. Good risks tend to subsidize bad ones. If insurance is bought only for the exposures which are more dangerous and difficult to price, it is all too clear what happens to the insurer's book.

Fifth, in the long-tailed liability lines, whoever holds the premiums gets to earn compound interest for a long time. Insurers are under pressure to give up those earnings or part of them.

But those investable funds are not free. The losses will eventually have to be paid. Once the premium is set, the insurer has the risk of having forecast the ultimate loss payment badly.

Setting a price for insurance for legal liability involves, in addition to underwriting judgments about occurrence, estimates about future price levels, future liability rules, future standards of care and of proof, and future measures for damage awards.

Many a banker finds it challenging enough to forecast interest rates six months ahead. Here we are forecasting many and more complex and interacting factors not months but years ahead. In some lines it can hardly be done at all.

Compound interest from holding premiums is the only significant cushion for error the insurer and reinsurer can have making those heroic estimates. Even compound interest is unlikely to be a fully adequate cushion, for interest rates are not intended to compensate for such extreme uncertainties.

Without the interest cushion, the insurer and reinsurer are just gambling. For them to price to an underwriting loss is for them to plan to give up some or all of the cushion. Even when the present competitive episode is over, we may find that it has set us on a false course for a long time.

Over the history of the insurance business, the underwriting return has gone for current expenses and rewards to managers, and the investment return has been a reward for capital and a source of recommitted financial strength for the future. We have it today because our predecessors had faith in the future and invested in the future. Why should we be the ones to give up ?

Indeed, nothing we have said here implies any of us should give up. We simply live in interesting times, and nobody promised us it would be easy.

Today, all of us, primary companies and reinsurers, brokers and agents, alike, have a great deal at stake in our individual abilities to select markets, to attract customers and then to underwrite and price their exposures consistently with our chosen business objectives.

All today's marketplace is telling us is that being average will no longer be adequate. It is not telling any of us we have to be average. Indeed it has given us all fair warning that the norm is not the place to be. 